CWE internship under the Career Center to develop community partners. Students sign up for one unit and work with a faculty mentor and community partners such as La Purísima Mission, Adamson House, Santa Barbara Food Bank Empty Bowls, and Santa Maria Open Streets to develop individual research goals. All CWE research projects in 3D Fine Arts are designed to culminate in signature events such as pop-up exhibits and peer-to-peer learning workshops. Additionally, all CWE projects stress elements of service learning.

La Purísima Concepción De María Santísima was founded in 1787 and was the 11th of 21 Franciscan Missions in California. One artifact in its collection was broken in an earthquake, and a California State Parks employee contacted the college seeking an interested student to re-create the object. CWE student Margaret Barker was paired with La Purísima with oversight from the instructor. Barker was prepared for the historical reproduction project because of her work in the Ceramics Workshop class. During the previous semester, Barker had taken soil samples from her grandfather's vineyard to create a refined slip as a coating on her relatively large-scale ceramic objects. For the Purísima project, Barker worked to reproduce the historical form, which was approximately 12 inches in diameter at the base, 12 inches in diameter at the throat, 30 inches at the circumference at the fullest point, and 18 inches in height, which were measurements of the historical vessel provided by California State Parks. Based on observations of photographs and sherds, Barker researched handbuilding processes necessary for the re-creation of the object. She combined a coil-building and paddling process, carefully following a template of the profile as she built the clay from the base upward. The template was prepared, taking into consideration the shrinkage rate of the clay body in the drying and firing process. According to her self-determined objectives, Barker completed a slideshow documentation of her process, wrote a reflection on her research experiences, and created a historical reproduction using hand-building techniques and terrasigillata specific to the region. Her piece is now part of the La Purísima Mission exhibit.

Undergraduate research at the college has been solely student/faculty driven. In particular, the Fine Arts Program reframes objectives inherent to creative problem-solving. High-impact practices and student-centered pedagogy develop critical thinking skills and a research mind-set. Aspects of this project have been presented in the form of signature class events that a faculty member featured in a professional development lecture for the college.

Such collaborative projects demonstrate how the arts can be supported by deliberate and intentional local partnerships while strengthening ties with the community.

60 Scholarship and Practice of Undergraduate Research

\section{Spreading Undergraduate Research Experiences across a Community College}

Angelo Kolokithas

NortheastWisconsin Technical College,Angelo.kolokithas@nwtc.edu

\section{doi: $10.18833 /$ spur/4/3/4}

Undergraduate research, although common at the university level, has been a slowly growing endeavor at community and technical colleges around the nation. Reasons for this situation include the mission of community and technical colleges, cost, and faculty workload. However, the proposed and realized impacts of authentic undergraduate research experiences on student success make these worthwhile activities for students at two-year institutions (Adedokun et al. 2014; Balster et al. 2010; Corwin, Graham, and Dolan 2015; Fechheimer, Webber, and Kleiber 2011; Kelly et al. 2007; Nadelson, Walters, and Waterman 2010). This vignette discusses the impacts of undergraduate research experiences on the students of Northeast Wisconsin Technical College (NWTC) through models for course and summer undergraduate research experiences (CURE and SURE, respectively; Kolokithas and Calderón 2018).

For the CURE, instructors at NWTC have joined the Tiny Earth Initiative (Tiny Earth n.d.), a network of students and instructors that focuses on student sourcing of antibiotics from soil. The World Health Organization has declared that an era is coming in which once simple infections treatable by antibiotics will be deadly again (Nisnevitch 2016). Although some institutions participate with a course section or two, it was decided that all sections of the Microbiology course at NWTC would join in the search for antibiotics. The Tiny Earth initiative shares curriculum, resources, and training for interested partners, which makes the transition into this model relatively simple to adopt. The labs involve collecting soil, isolating bacteria, screening for antibiotic producers, and identifying genotypes and phenotypes. Further isolation of antimicrobial substances and eukaryotic testing also can be done.

At NWTC, the Tiny Earth initiative curriculum has been in place for the past three years, and the results have been quite positive. Students were surveyed before and after completion of their course. Students were asked a range of questions, including applicability of the subject to their daily lives. Before the adoption of the Tiny Earth curriculum at NWTC, the perception of students that microbiology was applicable or very applicable to their daily lives, not just their program, increased from 23 percent of students in the presurvey to 50 percent of students in the postsurvey $(n=75)$. However, when the Tiny Earth curriculum was adopted, students seemed to have a better appreciation of the applicability of microbiology to their daily lives, as the data collected showed an increase from 
32 percent of students in the presurvey to 70 percent in the postsurvey $(n=152)$. Comments on the surveys indicated the students were excited to be a part of a worldwide movement and to potentially find a new antibiotic that could save countless lives.

In fall 2018 and fall 2019, NWTC and the Tiny Earth Initiative, as well as several colleges and universities in Wisconsin, teamed up with the Green Bay Packers to have a poster symposium of student work at the Packers' Lambeau Field. The NWTC students were required to involve the community in their soil acquisition, comparing two sites for antibiotic-producing bacteria. This was done not only to potentially discover new antibiotics but also to raise awareness and educate the community on the problem of antibiotic resistance. Over the two fall semesters, 250 allied health NWTC students-most in their third term of college-produced 140 high-quality posters for the Tiny Earth in Titletown annual symposium, which many community members attended.

At NWTC, many students are unable to commit to fulltime science internships, as they have other commitments. To address this situation, a SURE was created in which students commit to an internship in virology research of 8 hours a week for 10 weeks (the minimum required for science programming at NWTC). Students were able to agree to this time frame and, after training, were quickly executing their own experiments and troubleshooting results. For the past three summers, students have progressively moved research forward and have learned how cellular restriction factors restrict viral infectivity.

These CUREs and SUREs have been so successful that the college had started a new initiative to spread these models into other disciplines at the college. A committee has been created to oversee the process of interested instructors proposing UREs and the provision of college resources to support them. In time, it is expected that these UREs will result in greater student success across the college.

\section{References}

Adedokun, Omolola A., Loran Carleton Parker, Amy Childress, Wilella D. Burgess, Robin Adams, Christopher R. Agnew, James F. Leary, et al. 2014. "Effect of Time on Perceived Gains from an Undergraduate Research Program." CBE-Life Sciences Education 13(1): 139-148. doi: 10.1187/cbe.13-03-0045

Balster, Nick J., Christine Pfund, Raelyn Rediske, and Janet Branchaw. 2010. "Entering Research: A Course That Creates Community and Structure for Beginning Undergraduate Researchers in the STEM Disciplines." CBE-Life Sciences Education 9: 108-118. doi: 10.1187/cbe.09-10-0073

Corwin, Lisa A., Mark J. Graham, and Erin L. Dolan. 2015. "Modeling Course-Based Undergraduate Research Experiences: An Agenda for Future Research and Evaluation." CBE- Life Sciences Education 14: 1-13. doi: 10.1187/cbe.14-10-0167
Fechheimer, Marcus, Karen L. Webber, and Pamela B. Kleiber. 2011. "How Well Do Undergraduate Research Programs Promote Engagement and Success of Students?" CBE-Life Sciences Education 10: 156-163. doi: 10.1187/cbe.10-10-0130

Kelly, Thomas, Elizabeth Ann Coleman, E. Kim Fifer, E. Robert Burns, Clifton Orr, and Richard W. Nicholas. 2007. "Partners in Research: Benefits of a Summer Research Program." Journal of Cancer Education 21: 243-247. doi: $10.1080 / 08858190701347853$

Kolokithas, Angelo, and Olga Calderón. 2018. “A How-to Guide on Bringing Undergraduate Research to Community and Technical Colleges." Journal of Microbiology \& Biology Education 19(3). doi: 10.1128/jmbe.v19i3.1653

Nadelson, Louis S., Linda J. Walters, and Jane M. Waterman. 2010. "Course-Integrated Undergraduate Research Experiences Structured at Different Levels of Inquiry." Journal of STEM Education: Innovations and Research 11(1-2): 27-44.

Nisnevitch, Marina. 2016. "Antibiotic Resistance and Antibiotic Alternatives: Looking towards the Future." Science Progress 99(1): 92-96. doi: 10.3184/003685016x 14508101433812

Tiny Earth. n.d. "Welcome to Tiny Earth!" Accessed March 22, 2021. https://tinyearth.wisc.edu/

\section{Accessibility in Undergraduate Research Experiences: A Novel CURE}

Todd Pagano, Morgan Bida, Annemarie D. Ross, and Susan Smith Pagano

Rochester Institute of Technology, tepnts@rit.edu

\section{doi: $10.18833 /$ spur/4/3/5}

Course-based undergraduate research experiences (CUREs) can have profound and lasting impacts on students. CURE participants often show gains in content knowledge, self-confidence, and enculturation into their field of study. Exciting is the recent momentum in providing CUREs at the two-year degree level (Hensel 2018; Patton and Hause 2020). However, the impacts of CUREs on students with disabilities-particularly those at the associate degree level-are not yet fully understood.

CURE courses were developed for Deaf and Hard-ofHearing $(\mathrm{D} / \mathrm{HH})$ students in the Laboratory Science Technology (LST) program (Lynn et al. 2020) at the National Technical Institute for the Deaf (NTID) of Rochester Institute of Technology (RIT). Notably, the developed CUREs enrolled all $\mathrm{D} / \mathrm{HH}$ students and also fulfilled a requirement for the two-year degree program. Attending to accessibility, the courses were taught in American Sign Language and focused on best practices for working with $\mathrm{D} / \mathrm{HH}$ students in the laboratory. Best practices included using different modalities/guidelines for clear communication, optimizing visibility in the laboratory, and seeking continual feedback from participants (Smith, Ross, and Pagano 2016). 